\title{
Analisis Kemandirian Belajar Matematika Siswa SMA Kelas XI Selama Pembelajaran Jarak Jauh
}

\author{
Nia Kurniasih $₫$ | Fitri Hidayani 1 | Abdul Muchlis $₫ \mid$ Joko Soebagyo
}

How to cite : Kurniasih, D., Hindayani, S., Muchlis, A, \& J., Soebagyo,. Analisis Kemandirian Belajar Matematika Siswa SMA Kelas XI Selama Pembelajaran Jarak Jauh, International Journal of Progressive Mathematics Education. 1(2).117-126. https://doi.org/10.22236/ijopme.v1i2.6568

To link to this article : https://doi.org/10.22236/ijopme.v1i2.6568

(C)2021. The Author(s). This open access article is distributed under a Creative Commons Attribution (CC BY-SA) 4.0 license.

Published Online on Agustus 14, 2021




\title{
Analisis Kemandirian Belajar Matematika Siswa SMA Kelas XI Selama Pembelajaran Jarak Jauh
}

\author{
Nia Kurniasih ${ }^{1,2}$,Fitri Hidayaniं ${ }^{3}$ Abdul Muchlis ${ }^{3}$ Joko Soebagyo $\square^{3}$ \\ Received: February 20, $2021 \quad$ Accepted: August 7, $2021 \quad$ Published Online: August 14, 2021
}

\begin{abstract}
Abstrak.
Latar Belakang.Kemandirian belajar merupakan salah satu tujuan yang harus dicapai dalam diri siswa sebagai tanda perkembangan siswa mampu mengatur dan mengarahkan dirinya menjadi lebih baik. Kemandirian belajar sangat dipengaruhi oleh beberapa factor di antaranya memeiliki kecintaan terhadap belajar, mempunyai kepercayaan diri, menerima tantangan belajar, rasa ingin tahu yang tinggi dan menerima tanggung jawab. Tujuan Penelitian ini untuk menganalisa besar kemandirian siswa selama pembelajaran jarak jauh. Sampel pada penelitian ini 105 siswa SMA Kelas XI. Metode Penelitian yang digunakan adalah studi kasus dengan menggunakan obesrvasi berupa angket dan melakukan wawancara terhadap 3 siswa. Hasil Penelitian menunjukkan standar deviasi pada respon pernyataan positif dan negative selalu lebih kecil dari reratanya, hal ini menunjukkan bahwa setiap anggota sampel mempunyai kesamaan respon. Keadaan saat ini yaitu terjadinya wabah COVID-19 pada awalnya membuat banyak siswa tidak siap dengan pembelajaran jarak jauh. Seiring berjalannya waktu pembelajaran jarak jauh ini diterima siswa. Bahkan siswa melihat hal-hal positif selama pembelajaran jarak jauh ini seperti meminimalisir waktu perjalanan, waktu belajar di luar kelas online lebih fleksibel. Selain itu siswa lebih banyak cara dan pilihan dalam menyelesaikan soal matematika lewat platform online. Kesimpulannya dengan adanya pembelajaran jarak jauh saat ini akibat terjadinya wabah COVID-19 mengubah cara pandang siswa terhadap proses belajar, yang semula ada ketakutan karena ketidakmampuan secara bertahap siswa dapat mengatasi ketakutan tersebut.
\end{abstract}

Kata Kunci : Wabah COVID-19, Pembelajaran Jarak jauh, Kemandirian Belajar.

(1) (2) 2021. The Author(s). This open access article is distributed under a Creative Commons Attribution (CC BY-SA) 4.0 license.

Nia Kurniasih

nia.kurniasih89@gmail.com

Fitri Hidayani

fitrihy990@gmail.com

Abdul Muchlis

muchilisabd@gmail.com

$\triangle$ Joko Soebagyo

joko_soebagyo@uhamka.ac.id

1 Sekolah Menengah Atas Negeri 1 Jakarta Utara, Indonesia

2 Sekolah Menengah Atas Muhammadiyah 8 Jakarta Timur, Indonesia

3 Universitas Muhammadiyah Prof. DR. HAMKA, Jakarta, Indonesia 


\section{Latar Belakang}

Wabah COVID-19 sempat dikhawatirkan oleh masyarakat Indonesia di awal tahun 2020 sampai pada akhirnya pada tanggal 26 Maret 2020 Pemerintah Indonesia mengumumkan jumlah orang yang terinfeksi COVID-19 sebanyak 790 orang(Ryalino, 2020). Dengan mewabahnya COVID-19 secara global mengubah cara dan pola hidup kita hampir di semua aspek kehidupan, salah satunya aspek pendidikan(Hartshorne et al., 2020; Papouli et al., 2020; Romero-Rodriguez et al., 2020). Dengan kondisi ini memaksa hampir semua lembaga pendidikan mengubah pola pembelajaran dari tatap muka langsung di sekolah atau di kampus ke pembelajaran jarak jauh secara online. Perubahan pola pembelajaran ini berlangsung sangat mendadak dan membuat hampir semua lembaga pendidikan tidak siap. Bahkan banyak pengajar yang merasa kesulitan dan stress untuk dapat menemukan pola pembelajaran online yang efektif(Hartshorne et al., 2020; Mailizar et al., 2020).

Siswa pun sangat terkejut akan perubahan yang mendadak ini, bahkan tidak menerima pembelajaran online, banyak dari mereka lebih memilih pembelajaran tatap muka langsung di sekolah. Hal ini dikarenakan timbulnya pertanyaan dalam diri siswa apakah pembelajaran online ini nyaman untuk mereka jalani dan mampukah mereka menjalaninya(Van Wart et al., 2020). Pembelajaran online menuntut siswa untuk lebih banyak melibatkan dirinya secara penuh dalam pembelajaran secara mandiri demi tercapainya tujuan pendidikan(Abuhassna et al., 2020; Paletta, 2014). Kemandirian belajar merupakan salah satu tujuan yang harus dicapai dalam proses pembelajaran. Melalui proses belajar dan pengalaman kemandirian belajar dalam diri siswa dapat terbentuk sebagai tanda perkembangan siswa dapat mengarahkan dan mengatur dirinya menjadi lebih baik(Hargreaves et al., 2013; lii et al., 2017). Kemandirian belajar sangat dipengaruhi oleh beberapa faktor seperti faktor psikologi dan lingkungan, seperti lingkungan sekolah, keluarga dan suasana rumah. Karena faktanya siswa dapat belajar mandiri tidak begitu saja ada dengan sendirinya(Isnawati et al., 2010; Kosko \& Wilkins, 2015).

Beberapa hal yang dapat menggambarkan seseorang memiliki kemandirian belajar bukan hanya terletak pada mau atau tidak mau seseorang itu mandiri. Kemandirian belajar seseorang memiliki indikator sebagai berikut: memiliki kecintaan terhadap belajar, kepercayaan diri sebagai siswa, keterbukaan terhadap tantangan belajar, sifat ingin tahu, pemahaman diri dalam hal belajar, dan menerima tanggung jawab untuk kegiatan belajarnya (Rafiee \& Abbasian-Naghneh, 2020; Tahar \& Enceng, 2006). Mudjiman, (2008) kemandirian belajar adalah sifat dan kemampuan siswa untuk belajar aktif didorong niat dan motivasi yang tinggi untuk dapat menguasi kemampuan tertentu yang telah dimilikinya. Begitu pentingnya kemandirian dalam belajar menjadikan siswa cenderung bersikap tenang dalam menghadapi masalah dalam belajarnya karena mempunyai kepercayaan diri yang tinggi dalam menyelesaikan masalah dan tugas-tugasnya(Handayani \& Hidayat, 2018; Muir \& Geiger, 2016; Paletta, 2014). Dari penjabaran di atas tentang kemandirian belajar yang harus dicapai siswa pada saat pandemi COVID-19, peneliti tertarik untuk melakukan penelitian Änalisis Kemandirian Belajar Matematika Siswa Selama Pembelajaran Online". 


\section{Kajian Teori}

\subsection{Kemandirian Belajar Matematika Siswa}

Kemandirian belajar siswa saat ini menjadi kunci utama dalam proses pembelajaran matematika. Kemandirian dimulai harus dimulai dikembangkan oleh siswa karena kemandirian belajar matematika berpengaruh besar terhadap pencapaian akademik siswa. Siswa yang tidak mengatur jadwal kegiatan belajarnya dengan baik, akan berdampak buruk terhadap pencapain prestasinya(Özcan, 2016; Ramo et al., 2010; Ranti et al., 2017). Dengan kemandirian belajar matematika, siswa diminta untuk mengatur banyak kegiatan belajar seperti mengerjakan tugas, menyelesaikan tugas kelompok, mengumpulkan tugas, dan mencari referensi belajar lainnya. Oleh karena itu, guru perlu mengingatkan dan mendorong siswa untuk menumbuhkan dan mengembangkan sikap kemandirian belajar.

Kemandirian belajar siswa yang sangat beragam dalam suatu kelas menjadi tantangan tersendiri bagi guru. Dalam memahami berbagai karakteristik siswa, guru perlu banyak berkomunikasi dengan siswa baik secara formal ataupun informal. Kegiatan komunikasi yang dilakukan oleh guru bermanfaat untuk mengindentifikasi kemandirian belajar siswa(Aziz \& Akgül, 2020; Hastuti et al., 2021). Komunikasi yang baik antar guru dan siswa akan memudahkan guru dalam mengetahui banyak hal baik akademik dan non-akademik. Ketika komunikasi itu terbangun dengan baik, maka guru dapat mengindentifikasi siswa-siswa yang memiliki kemandirian belajar yang tinggi, sedang, dan rendah. Kemampuan guru untuk mengidentifikasi kemandirian belajar siswa sangat bermanfaat dalam menentukan model pembelajaran yang tepat bagi siswa.

\subsection{Kemandirian Siswa Dalam Pembelajaran Matematika Jarak Jauh}

Kemandirian belajar matematika siswa dalam pembelajaran jarak jauh menjadi salah satu faktor pendukung utama dalam mencapai tujuan pembelajaran matematika siswa(Bekdemir, 2010; F, Pajares., \& M. D, 1994; Krawitz \& Schukajlow, 2017). Dalam pembelajaran matematika secara jarak jauh, guru menyiapkan berbagi hal seperti materi pelajaran yang akan disebarluaskan, link pertemuan secara online, penilaian online, daftar hadir online, dan banyak hal lainnya. Dengan banyaknya beban pekerjaan yang diberikan kepada guru, guru hanya berharap siswa membaca serta mempelajari materi pelajaran terlebih dahulu dan mengidentifikasi materi-materi yang dirasa perlu ditanyakan. Namun, faktanya banyak sekali siswa yang tidak membaca materi yang sudah dipersiapkan oleh guru. Bahkan tidak jarang, guru harus mengajarkan kembali materi-materi yang sudah dipelajari pada pertemuan sebelumnya. Hal ini terjadi karena rendahnya kemandirian belajar matematika siswa.

Dengan kemandirian yang dimiliki, siswa didorong untuk tidak tergantung pada penjelasan yang disampaikan oleh guru(Mcconatha et al., 2008; Zhang \& Wu, 2016). Siswa dapat mencari penjelasan materi dari berbagai sumber belajar yang tersedia secara online baik berbayar ataupun gratis(Avsec \& Kocijancic, 2014; Schraw \& Robinson, 2011). Keterbatasan waktu dan minimnya fasilitas yang diperlukan dalam proses pembelajaran secara jarak jauh, maka siswa perlu didorong menginisiasi kemandirian belajar matematika. Dengan kemandirian belajar matematika, siswa 
tidak hanya tergantung pada guru, tapi dapat menginisiasi banyak hal seperti belajar secara berkelompok, bertanya pada Whatsapps group, dan mencari sumber belajar lainnya.

\section{Metode Penelitian}

Metode penelitian yang digunakan adalah metode studi kasus. Hartley (2004), menyatakan bahwa penelitian studi kasus adalah penyelidikan yang rinci dan detail tentang suatu fenomena yang terjadi pada waktu tertentu, dengan tujuan memberikan analisis konteks dan penjelasan masalah teoritis yang sedang dipelajari. Data studi kasus dapat diperoleh dengan pendekatan penelitian deskriptif kualitatif untuk menganalisa deskripsi fenomena yang terjadi(Kohlbacher, 2006; Raj Acharya, 2017). Menurut Gall, Gall \& Borg, 2007, alat obesrvasi yang sering digunakan pada penelitian deskriptif ini adalah survei dan penyajian datanya sering disajikan dengan menggunakan frekuensi, rata-rata atau analisis statistik lainnya untuk menentukan hubungan(Nassaji, 2015).

Pada penelitian ini peneliti mengadakan survei dengan mengajukan pertanyaan-pertanyaan tentang kemandirian belajar selama pembelajaran online dalam bentuk angket yang disebar melalui Google Forms. Angket diupload pada tanggal 28 November 2020 dan ditutup pada tanggal 30 November 2020. Terdapat 105 Siswa Kelas XI yang mengikuti dan mengembalikan angket, terdiri dari $\mathbf{4 6}$ siswa laki-laki dan $\mathbf{5 9}$ siswa perempuan.

Setelah data survei diperoleh peneliti melakukan triangulasi yaitu penggunaan data survei untuk wawancara. Langkah ini untuk memperoleh validasi klaim yang mungkin muncul dari hasil survei(Burgess \& Murcott, 2014). Wawancara dilakukan peneliti kepada tiga orang siswa diantara 105 siswa yang mengikuti survei angket.

\section{Tabel 1. Demografi subjek penelitian}

\begin{tabular}{lccc}
\multicolumn{1}{c}{ Kategori } & Label & Jumlah & $\%$ \\
\hline Jenis Kelamin & & & \\
\hline Laki-laki & $\mathrm{L}$ & 46 & 43,81 \\
Perempuan & $\mathrm{P}$ & 59 & 56,19 \\
\hline Kelas & & & 17,1 \\
\hline Kelas A & V1 & 18 & 21 \\
Kelas B & V2 & 22 & 17,1 \\
Kelas C & V3 & 18 & 22,9 \\
Kelas D & V4 & 24 & 21,9 \\
Kelas E & V5 & 23 & \\
\hline Alat utama selama belajar dari jauh & & 13 & \\
\hline Handphone & A1 & 25 & \\
Laptop & A2 & 67 & \\
Handphone dan Laptop & A3 & & \\
\hline
\end{tabular}


Angket Kemandirian Belajar Siswa terdiri dari 30 pertanyaan dari 7 indikator utama. 7 indikator utama pertanyaan pada angket adalah:

1. Inisiatif belajar

2. Mendiagnosa kebutuhan belajar

3. Menetapkan target/tujuan belajar

4. Memandang kesulitan sebagai tantangan

5. Memanfaatkan dan mencari sumber matematika yang relevan

6. Memilih dan menerapkan strategi belajar

7. Konsep diri

Pertanyaan-pertanyaan tersebut peneliti adopsi dari Buku Hard Skills dan Soft Skills Matematika Siswa(Hendriana, Heris and Euis Eti Rohaeti, n.d.). Pemberian skor pada butir soal terdiri atas 4 kategori bertingkat yaitu (1) sangat setuju, (2) setuju, (3) tidak setuju, dan (4) sangat tidak setuju. Jenis pertanyaan dalam angket adalah pernyataan positif dan negatif.

\begin{tabular}{|c|c|c|c|}
\hline No & Indikator & Nomor Item & Jumlah \\
\hline 1 & Inisiatif belajar & $1(+), 2(+), 3(+), 4(+), 5(+)$ & 5 \\
\hline 2 & Mendiagnosa kebutuhan belajar & $1(+), 2(-), 3(+), 4(+)$ & 4 \\
\hline 3 & Menetapkan target/tujuan belajar & $1(+), 2(+), 3(-), 4(+)$ & 4 \\
\hline 4 & Memandang kesulitan sebagai tantangan & $1(-), 2(+), 3(-), 4(+), 5(+)$ & 5 \\
\hline 5 & $\begin{array}{l}\text { Memanfaatkan dan mencari sumber } \\
\text { matematika yang relevan }\end{array}$ & $1(+), 2(+), 3(+), 4(+)$ & 4 \\
\hline 6 & Memilih dan menerapkan strategi belajar & $1(+), 2(+), 3(+), 4(+)$ & 4 \\
\hline 7 & Konsep diri & $1(-), 2(+), 3(-), 4(+)$ & 4 \\
\hline \multicolumn{2}{|c|}{ Jumlah Butir } & \multicolumn{2}{|l|}{30} \\
\hline
\end{tabular}

\section{HASIL PENELITIAN}

Hasil Analisis Deskriptif

Berdasarkan setiap pernyataan dalam angket, keseluruhan responden menunjukkan kemandirian belajar matematika selama pembelajaran online sebagai berikut:

\section{Tabel 3 Pernyataan Angket}

\begin{tabular}{llcccc}
\multirow{2}{*}{ No } & \multicolumn{1}{c}{ Indikator } & \multicolumn{2}{c}{ Respon positif } & \multicolumn{2}{c}{ Respon negatif } \\
& & Mean & SD & Mean & SD \\
\hline 1 & Inisiatif belajar & 62,2 & 26,9 & 28,34 & 17,4 \\
2 & Mendiagnosa kebutuhan belajar & 69 & 27,36 & 35,75 & 27,11 \\
3 & Menetapkan target/tujuan belajar & 64 & 9,13 & 41 & 9,13 \\
4 & Memandang kesulitan sebagai tantangan & 53,2 & 14,3 & 51,8 & 14,3 \\
5 & Memanfaatkan dan mencari sumber & 77,25 & 15,22 & 27,75 & 15,22 \\
& matematika yang relevan & & & & \\
6 & Memilih dan menerapkan strategi belajar & 76,25 & 17,67 & 28,5 & 17,23 \\
7 & Konsep diri & 66,75 & 14,38 & 37,75 & 14,24 \\
\hline & Berdasarkan tabel di atas terlihat standar deviasi pada respon pernyatan positif dan
\end{tabular}

negatif selalu lebih kecil dari reratanya. Hal ini menunjukkan bahwa setiap anggota sampel mempunyai kesamaan respon. Artinya tidak adanya perbedaan respon yang jauh di antara siswa. Apabila dirinci per indikator terlihat bahwa rerata pada respon positif masih lebih besar dari rerata 
pada respon negatif, ini artinya secara garis besar banyak siswa yang dengan cepat menerima pembelajaran online sehingga memotivasi siswa untuk lebih mandiri dalam proses belajar. Sebagai penguat klaim pada data hasil angket, peneliti melakukan wawancara dengan tiga orang siswa yang terpilih dari 105 siswa yang memberikan respon angket.

Berdasarkan hasil wawancara peneliti mencatat bahwa pada awal ditetapkannya pembelajaran online siswa banyak yang terkejut, merasa tidak siap dan merasa tidak mampu menjalani proses pembelajaran online tersebut. Seiring berjalannya waktu siswa saling memotivasi di antara siswa sehingga siswa mulai menemui cara untuk dapat belajar secara mandiri selama pembelajaran online. Banyak keuntungan yang siswa dapatkan selama pembelajaran online di antaranya banyaknya waktu yang dapat siswa gunakan untuk belajar dan mencari sumber bahan pelajaran melalui beberapa platform di internet(Blaine, 2019; Drijvers, 2020; Kosko \& Wilkins, 2015). Dengan menggunakan media sosial siswa masih dapat bekerja sama dengan siswa lainnya untuk menyelesaikan tugas-tugas pada pembelajaran online. Hal itulah di antaranya yang memotivasi siswa dapat belajar secara mandiri selama pembelajaran online(George, 2012; Machmud et al., 2021). Beberapa hal yang menjadi perhatian siswa selama pembelajaran online adalah kadang muncul rasa jenuh dan lelah karena selama berjam-jam dalam pembelajaran online(Hasan \& Bao, 2020), siswa hanya duduk di depan komputer mendengarkan penjelasan dan instruksi guru. Seiring berjalannya waktu dan perkembangan kasus yang ada di beberapa daerah, siswa memahami dan menerima bahwa pembelajaran online ini merupakan solusi terbaik untuk dapat terus belajar pada saat ini.

Dengan terjadinya wabah COVID-19 banyak perubahan dalam segala aspek kehidupan kita berubah dalam waktu relatif singkat, demikian halnya delam aspek pendidikan. Penggunaan platform belajar mengajar berubah secara mendadak dari pembelajaran tatap muka menjadi pembelajaran online(Hartshorne et al., 2020; Hjalmarson, 2017). Seiring berjalannya waktu, para siswa harus dapat beradaptasi dengan cepat dalam pelaksanaan pembelajaran secara online karena struktur pengajaran online sudah terstruktur dan terpola sehingga siswa dapat merasakan kenyamanan dalam pembelajaran online ini(Blaine, 2019; Cook \& Thompson, 2014). Pada pembelajaran online ini siswa mengungkapkan kerinduan mereka terhadap pembelajaran tatap muka di sekolah seperti pada waktu sebelum pandemi, hal ini dikarenakan siswa mempunyai pengalaman mendapatkan respon yang cepat dari para guru ketika mereka menemukan kesulitankesulitan dalam menyelesaikan soal matematika ataupun dalam proses pembelajaran. Di lain sisi siswa mengakui bahwa inisiatif belajar mereka lebih tinggi dari pada saat pembelajaran tatap muka di sekolah. Hal ini dikarenakan adanya hal-hal yang dialami saat pembelajaran tatap langsung dapat diminimalisir saat pembelajaran online, seperti waktu perjalanan dari rumah ke sekolah, kelelahan setelah mengalami perjalanan pulang pergi ke sekolah, sehingga waktu belajar lebih fleksibel(Hjalmarson, 2017). Selain itu, dalam pembelajaran online ini siswa lebih banyak cara dan pilihan dalam menyelesaikan soal matematika lewat platform online ataupun situs-situs pendukung pembelajaran online. Dengan banyaknya platform online yang berbeda menjadikan siswa mempunyai kemampuan untuk beradaptasi dalam menggunakannya sehingga platform online tersebut membantu dan mendukung siswa mempersiapkan diri dalam pembelajaran online. Pada pembelajaran online ini platform online mempunyai peranan yang sangat penting dalam memberikan pengalaman belajar online meskipun secara fisik siswa terpisah dari gurunya 
sehingga hal ini meningkatkan kemandirian siswa dalam belajar (Abuhassna et al., 2020; Kosiret et al., 2021; Umam et al., 2019).

Menurut Bates dan Galloway, (2012) metode pengajaran online bisa jadi merupakan metode yang efisien dalam menyampaikan konten pembelajaran tetapi tidak memungkinkan untuk dapat mengembangkan pembelajaran aktif dan menyalurkan minat siswa. Hal ini diaminkan oleh Sutterlin, 2018, bahwa dengan tidak adanya interaksi dengan teman sebaya meniadakan pembelajaran aktif maka pembelajaran online digambarkan seperti buku interaktif dari pada sebagai ruang kelas. Hodges et al, 2020, mengakui bahwa pembelajaran online dapat menjadi pembelajaran aktif sepanjang pembelajaran online tersebut dirancang dengan sangat baik, sehingga pembelajaran online aktif menjadi solusi positif dalam merespon krisis yang terjadi saat ini(Hew et al., 2020; Ni et al., 2018). Dalam penelitiannya Yamamoto menyajikan 3 gaya belajar untuk mengetahui tingkat efektifitas proses dan hasil belajar, salah satunya adalah pembelajaran online. Pada pembelajaran online didapat terdapat efektifitas dalam penggunaan waktu sebesar $24 \%$ dibandingkan pembelajaran tatap muka. Yamamoto merekomendasikan pembelajaran online yang menggunakan web agar terus dikembangkan(H. Yamamoto, n.d.).

\section{KESIMPULAN}

Dengan terjadinya wabah COVID-19 memaksa setiap orang untuk dapat merespon positif terhadap segala perubahan yang terjadi, termasuk para pengajar dan siswa. Perubahan pembelajaran tatap muka langsung mengubah cara pandang siswa terhadapa pembelajaran online, yang semula ada ketakutan ketidakmampuan siswa dalam belajar online, secara bertahap hal itu dapat siswa atasi dengan memanfaatkan waktu untuk mencari dan menambah sumber belajar dari platform yang ada di internet dan media sosial. Sehingga kemandirian siswa lebih baik lagi dari pada saat pembelajaran tatap muka langsung. Untuk para guru dan Lembaga Pendidikan merasa tertantang untuk dapat mengubah rencana penngajaran sebelum-sebelumnya menjadi rencana pengajaran baru yang dkhususkan untuk pengajaran online, sehingga pembelajaran online bisa menghasilkan pembelajaran aktif yang dapat meminimalisir kejenuhan siswa selama pembelajaran online.

\section{Identitas Penulis}

\section{Nia Kurniasih}

E-mail: niak100572@gmail.com

ORCID ID:

Fitri Hidayani

E-mail: fitrihidayani77@gmail.com

ORCID ID:

Abdul Muchlis

E-mail: bdlmuchlis@gmail.com

ORCID ID:

Joko Soebagyo

E-mail: joko_soebagyo@uhamka.ac.id

ORCID ID: 


\section{Conflict of Interest}

The authors state there is no conflict of interest

\section{Citation information}

Cite this article as: Kurniasih, D., Hindayani, S., Muchlis, A, \& J., Soebagyo,. Analisis Kemandirian Belajar Matematika Siswa SMA Kelas XI Selama Pembelajaran Jarak Jauh, International Journal of Progressive Mathematics Education. 1(2).117-126 https://doi.org/10.22236/ijopme.v111.6568

\section{DAFTAR PUSTAKA}

Abuhassna, H., Al-rahmi, W. M., Yahya, N., Aman, M., \& Megat, Z. (2020). Development of a new model on utilizing online learning platforms to improve students ' academic achievements and satisfaction.

Avsec, S., \& Kocijancic, S. (2014). Effectiveness of Inquiry-Based Learning: How do Middle School Students Learn to Maximise the Efficacy of a Water Turbine? International Journal of Engineering Education, 30(6), 1436-1449.

Aziz, T. A., \& Akgül, M. B. (2020). Proses Kognitif dan Metakognitif Siswa dalam Memecahkan Masalah Matematika. Jurnal Riset Pendidikan Matematika Jakarta, 2(2), $71-$ 86. https://doi.org/10.21009/irpmi.v2i1.10446

Bekdemir, M. (2010). The pre-service teachers' mathematics anxiety related to depth of negative experiences in mathematics classroom while they were students. Educational Studies in Mathematics, 75(3), 311-328. https://doi.org/10.1007/s10649-010-9260-7

Blaine, A. M. (2019). Interaction and presence in the virtual classroom: An analysis of the perceptions of students and teachers in online and blended Advanced Placement courses. Computers and Education, 132, 31-43. https://doi.org/10.1016/i.compedu.2019.01.004

Burgess, R., \& Murcott, A. (2014). Developments in sociology. Developments in Sociology, 1334. https://doi.org/10.4324/9781315838120

Cook, D. A., \& Thompson, W. G. (2014). Comfort and experience with online learning: Trends over nine years and associations with knowledge. BMC Medical Education, 14(1), 15. https://doi.org/10.1186/1472-6920-14-128

Drijvers, P. (2020). Digital Tools in Dutch Mathematics Education: A Dialectic Relationship. https://doi.org/10.1007/978-3-030-33824-4_10

F, Pajares., \& M. D, M. (1994). "Role of Self-Efficacy and Self-Concept Beliefs in Mathematical Problem Solving: A Path Analysis". Journal of Educational Psychology, 86. No. 2, 193-203.

George, M. (2012). Autonomy and Motivation in Remedial Mathematics. Primus, 22(4), 255264. https://doi.org/10.1080/10511970.2010.497958

H. Yamamoto, M. N. (Tokyo I. of T. (n.d.). Effectiveness of Various CAI Education Styles and Support Functions On Self Study. https://doi.org/10.1007/978-0-387-35393-7

Handayani, N., \& Hidayat, F. (2018). Hubungan Kemandirian terhadap Hasil Belajar Siswa Mata Pelajaran Matematika di kelas X SMK kota Cimahi. Journal on Education, 01(02), 1-8.

Hargreaves, E., Berry, R., Lai, Y. C., Leung, P., Scott, D., \& Stobart, G. (2013). Teachers' experiences of autonomy in Continuing Professional Development: Teacher Learning Communities in London and Hong Kong. Teacher Development, 17(1), 1934. https://doi.org/10.1080/13664530.2012.748686

Hartshorne, R., Baumgartner, E., Kaplan-rakowski, R., Mouza, C., \& Ferdig, R. (2020). Preservice and inservice professional development during the COVID-19 pandemic. Journal of Technology and Teacher Education, 28(2), 137-147.

Hasan, N., \& Bao, Y. (2020). Impact of "e-Learning crack-up" perception on psychological distress among college students during COVID-19 pandemic: A mediating role of "fear of academic year loss." 
Children and Youth Services Review, 118(July), 105355. https://doi.org/10.1016/i.childyouth.2020.105355

Hastuti, E. S., Eclarin, L., \& Dalam, K. K. S. (2021). Kecemasan Siswa Sekolah Menengah Pertama Menyelesaikan Masalah SPLDV Pada Kelas Virtual Dalam. International Journal of Progressive Mathematics Education, 1(1), 64-84. https://doi.org/10.22236/ijopme.v1i1.6914

Hendriana, Heris and Euis Eti Rohaeti, U. S. (n.d.). Heris Hendriana; Euis Eti Rohaeti; Utari Sumarmo. (2017). Hard skills dan soft skills matematik siswa / Heris Hendriana, Euis Eti Rohaeti, Utari Sumarmo. Bandung :: Refika Aditama,.

Hew, K. F., Jia, C., Gonda, D. E., \& Bai, S. (2020). Transitioning to the "new normal" of learning in unpredictable times: pedagogical practices and learning performance in fully online flipped classrooms. International Journal of Educational Technology in Higher Education, 17(1). https://doi.org/10.1186/s41239-020-00234-x

Hjalmarson, M. A. (2017). Learning to teach mathematics specialists in a synchronous online course: a selfstudy. Journal of Mathematics Teacher Education, 20(3), 281301. https://doi.org/10.1007/s10857-015-9323-x

lii, K., Negeri, S. D., \& Aceh, B. (2017). Analisis Kemandirian Siswa Dalam Proses Pembelajaran Di Kelas lii Sd Negeri 1 Banda Aceh. Pesona Dasar (Jurnal Pendidikan Dasar Dan Humaniora), 1(1), 70 81.

Isnawati, N., Samian, D., Prodi Pendidikan Akuntansi FKIP-UMS, A., \& Prodi Pendidikan Akuntansi FKIP UMS, D. (2010). Kemandirian Belajar Ditinjau Dari Kreativitas Belajar Dan Motivasi Belajar Mahasiswa. Journals.Ums.Ac.Id, 1, 128-144.

Kohlbacher, F. (2006). ePub WU Institutional Repository The Use of Qualitative Content Analysis in Case Study Research. Forum Qualitative Sozialforschung / Forum: Qualitative Social Research, 7(1), 21.

Kosiret, A., Indiyah, F. H., \& Wijayanti, D. A. (2021). The Use of Generative Learning Model in Improving Students' Understanding of Mathematical Concepts of Al-Azhar 19 Islamic High School. International Journal of Progressive Mathematics Education, 1(1), 1626. https://doi.org/10.22236/ijopme.v1i1.6593

Kosko, K. W., \& Wilkins, J. L. M. (2015). Does time matter in improving mathematical discussions? the influence of mathematical autonomy. Journal of Experimental Education, 83(3), 368385. https://doi.org/10.1080/00220973.2014.907225

Krawitz, J., \& Schukajlow, S. (2017). Do students value modelling problems, and are they confident they can solve such problems? Value and self-efficacy for modelling, word, and intra-mathematical problems. ZDM - Mathematics Education, 0(0), 0. https://doi.org/10.1007/s11858-017-0893-1

Machmud, M. T., Widiyan, A. P., \& Ramadhani, N. R. (2021). The development and policies of ICT supporting educational technology in Singapore, Thailand, Indonesia, and Myanmar. International Journal of Evaluation and Research in Education, 10(1), 7885. https://doi.org/10.11591/ijere.v10i1.20786

Mailizar, Almanthari, A., Maulina, S., \& Bruce, S. (2020). Secondary school mathematics teachers' views on e-learning implementation barriers during the COVID-19 pandemic: The case of Indonesia. Eurasia Journal of Mathematics, Science and Technology Education, 16(7). https://doi.org/10.29333/EJMSTE/8240

Mcconatha, D., Praul, M., \& Lynch, M. J. (2008). Mobile learning in higher education: An empirical assessment of a new educational tool. Turkish Online Journal of Educational Technology, 7(3), 15-21.

Mudjiman, H. (2008). Belajar mandiri / Penulis, Prof.Drs. Haris Mudjiman,M.A., Ph.D.; editor, Prof. Dr. Sri Anitah, M.Pd., Dr. sumarlan,MS., Kundharu Saddhono,S.S., M.Hum. (M. H. Prof. Dr. Sri Anitah, M.Pd., Dr. sumarlan, MS., Kundharu Saddhono, S.S. (ed.); Cetakan 2).

Muir, T., \& Geiger, V. (2016). The affordances of using a flipped classroom approach in the teaching of mathematics: a case study of a grade 10 mathematics class. Mathematics Education Research Journal, 28(1), 149-171. https://doi.org/10.1007/s13394-015-0165-8

Nassaji, H. (2015). Qualitative and descriptive research: Data type versus data analysis. Language Teaching Research, 19(2), 129-132. https://doi.org/10.1177/1362168815572747 
Ni, Y., Zhou, D. H. R., Cai, J., Li, X., Li, Q., \& Sun, I. X. (2018). Improving cognitive and affective learning outcomes of students through mathematics instructional tasks of high cognitive demand. Journal of Educational Research, 111(6), 704-719. https://doi.org/10.1080/00220671.2017.1402748

Özcan, Z. Ç. (2016). The relationship between mathematical problem-solving skills and self-regulated learning through homework behaviours, motivation, and metacognition. International Journal of Mathematical Education in Science and Technology, 47(3), 408420. https://doi.org/10.1080/0020739X.2015.1080313

Paletta, A. (2014). Improving Students' Learning Through School Autonomy: Evidence From the International Civic and Citizenship Survey. Journal of School Choice, 8(3), 381409. https://doi.org/10.1080/15582159.2014.942173

Papouli, E., Chatzifotiou, S., \& Tsairidis, C. (2020). The use of digital technology at home during the COVID19 outbreak:Views of social work students in Greece. Social Work Education, 39(8), 11071115. https://doi.org/10.1080/02615479.2020.1807496

Rafiee, M., \& Abbasian-Naghneh, S. (2020). Willingness to Write (WTW): Development of a model in EFL writing classrooms. Cogent Education, 7(1), 16. https://doi.org/10.1080/2331186X.2020.1847710

Raj Acharya, B. (2017). Factors Affecting Difficulties in Learning Mathematics by Mathematics Learners. International Journal of Elementary Education, 6(2), 8. https://doi.org/10.11648/j.jijeedu.20170602.11

Ramo, D. E., Myers, M. G., \& Brown, S. A. (2010). Self-efficacy mediates the relationship between depression and length of abstinence after treatment among youth but not among adults. Substance Use and Misuse, 45(13), 2301-2322. https://doi.org/10.3109/10826081003710304

Ranti, M. G., Budiarti, I., \& Trisna, B. N. (2017). Pengaruh Kemandirian Belajar (Self Regulated Learning) Terhadap Hasil Belajar Mahasiswa Pada Mata Kuliah Struktur Aljabar. Math Didactic, 3(1), 7583. https://doi.org/10.33654/math.v3i1.57

Romero-Rodriguez, J. M., Aznar-Diaz, I., Hinojo-Lucena, F. J., \& Gomez-Garcia, G. (2020). Mobile Learning in Higher Education: Structural Equation Model for Good Teaching Practices. IEEE Access, 8, 91761-91769. https://doi.org/10.1109/ACCESS.2020.2994967

Ryalino, C. (2020). How indonesia copes with coronavirus disease 2019 so far (part one): The country, the government, and the society. Bali Journal of Anesthesiology, 4(2), 33. https://doi.org/10.4103/bjoa.bjoa_34_20

Schraw, G., \& Robinson, D. H. (2011). Assessment of Higher Order Thinking Skills. Current Perspectives on Cognition, Learning and Instruction. In IAP - Information Age Publishing, Inc.

Tahar, I., \& Enceng. (2006). Hubungan Kemandirian Belajar Dan Hasil Belajar Pada Pendidikan Jarak Jauh. Jurnal Pendidka Terbuka Dan Jarak Jauh, 7(2), 91-101.

Umam, K., Nusantara, T., Parta, I. N., Hidayanto, E., \& Mulyono, H. (2019). An Application of Flipped Classroom in Mathematics Teacher Education Programme. International Journal of Interactive Mobile Technologies (IJIM), 13(03), 68. https://doi.org/10.3991/ijim.v13i03.10207

Van Wart, M., Ni, A., Medina, P., Canelon, J., Kordrostami, M., Zhang, J., \& Liu, Y. (2020). Integrating students' perspectives about online learning: a hierarchy of factors. International Journal of Educational Technology in Higher Education, 17(1). https://doi.org/10.1186/s41239-020-00229$\underline{8}$

Zhang, Q., \& Wu, F. (2016). State-of-the-Art and Future Directions of Smart Learning. In State-of-the-Art and Future Directions of Smart Learning (Y. Li et a, pp. 257-261). Lecture Notes in Educational Technology. https://doi.org/10.1007/978-981-287-868-7

\section{Funding}

The authors received no direct funding for this research.

\section{Citation information}

Publisher's Note UHAMKA Press remains neutral with regard to jurisdictional claims in published maps and institutional affiliations. 